\title{
Landscapes with Araucaria in South America: evidence for a cultural dimension
}

\author{
$\underline{\text { Maurício Sedrez dos Reis }}^{1}, \underline{\text { Ana Ladio }}^{2}$ and Nivaldo Peroni $^{3}$
}

\begin{abstract}
South American Araucaria species include Araucaria araucana (Mol.) C. Koch (Argentina and Chile) and Araucaria angustifolia (Bert.) O. Kuntze (Brazil and Argentina). Both species produce nut-like seeds (piñones, pinhões) that have, since preColumbian times, formed part of the traditional diet of local societies: Kaingang ( $A$. angustifolia) and Mapuche-Pehuenche (A. araucana). In this work, we compared and analyzed converging and diverging characteristics of these species founded on ecological and ethnobotanical evidence. We also studied the role of human groups in the construction of Araucaria forests. The methodology used was based on a bibliographical analysis that included a wide range of sources, from ecological to social sciences. Our results show that both species hold strong cultural and symbolic significance for associated human groups. The ecological characteristics of both species have favored their rapid territorial expansion since the Holocene; however, palynological, archaeological, and ethnobotanical evidence reinforces the hypothesis that the human groups involved played a key role in this process. For both societies, there are records of past and present practices related to the transport, storage, and processing of the seeds. The landscapes where $A$. araucana and $A$. angustifolia are present also reflect use patterns that hold a level of significance that goes beyond merely utilitarian purposes. For the Kaingang and the Mapuche-Pehuenche, the Araucaria forests are associated with the concept of territoriality and play a key role in determining their identity. Our approach to cultural landscapes, which considers the importance of societies in the modelling of natural landscapes, can offer new perspectives for conservation policies and action in both forests.
\end{abstract}

Key Words: Araucaria forests; Araucaria angustifolia; Araucaria araucana; cultural identity; cultural landscape; traditional diet

\section{INTRODUCTION}

Araucaria araucana (Mol.) C. Koch (commonly known as pehuén, araucaria, pino piñonero, or the monkey puzzle tree,) and Araucaria angsutifolia (Bert.) O. Kuntze (known as curi, curii, araucaria, pinheiro Brasileiro, pinheiro do paraná, or Brazilian pine) are the two Araucariaceae (or Araucaria) found in South America (Hueck 1972, Veblen et al. 1995, Kershaw and Wagstaff 2001). Both species produce nut-like seeds (known locally as "piñones" or "pinhões") of high nutritional value which, since pre-Columbian times, have formed part of the traditional diet of human populations that have lived in association with them. This has been the case with the pehuén for the Mapuche-Pehuenche people in the Andes in south-central Chile and Argentina, from pre-Columbian times to the present; and with the curi for the Kaingang people in southern Brazil, in pre-Columbian times; and smallholder farmers today (Ladio 2001, Guerra et al. 2002, Santos et al. 2002, Aagensen 2004, Herrmann 2006, Vieira da Silva and Reis 2009, Parque Nacional Lanín 2011).

The geographical distribution of A. angustifolia (Reitz and Klein 1966, Hueck 1972, Mattos 1994) includes the south of Brazil (Rio Grande do Sul, Santa Catarina and Paraná provinces) and the northeast of Argentina (Misiones province). However, in addition, this species is found in isolated patches in the southeast of Brazil (São Paulo, Minas Gerais and Rio de Janeiro provinces). Populations of this species occur between $18^{\circ} \mathrm{S}$ and $30^{\circ} \mathrm{S}$ latitude and 500-1800 $\mathrm{m}$ altitude, occupying a total area of approximately $200,000 \mathrm{~km}^{2}$ (Reitz and Klein 1966, Mattos 1994, Guerra et al. 2002; Fig. 1).
The geographical distribution of $A$. araucana comprises the latitudinal strip between $37^{\circ} \mathrm{S}$ and $42^{\circ} \mathrm{S}$, on both sides of the Andean mountain range, in almost continuous form in both Argentina and Chile (Hueck 1972, Veblen et al. 1995), covering an estimated total area of $5000 \mathrm{~km}^{2}$ (González et al. 2006; Fig. 1). In Argentina, its presence is restricted to Neuquén province, from the Andes mountains to the ecotonal zones bordering the Patagonian steppe, where small, unconnected populations are formed (Veblen et al. 1995, González et al. 2006). In Chile, the species is distributed east to west from the Andes mountains in the administrative regions VII, IX, and X, but two unconnected patches are also present in the Nahuelbuta Cordillera, close to the coast (Veblen et al. 1995, Echeverria et al. 2004). These populations occur at altitudes of between $900-1800 \mathrm{~m}$ in the Andean Cordillera and between $600-1000 \mathrm{~m}$ in the Nahuelbuta Cordillera (Veblen et al. 1995).

In their recent history, both species have suffered nonsustainable exploitation and a reduction in their distribution area for agricultural or forestry use (Guerra et al. 2002, Gonzalez et al. 2006, Zamorano et al. 2008, Ribeiro et al. 2009). In both cases, this process started at the beginning of the $20^{\text {th }}$ century, and in both regions this coincided with the advance of the socioeconomic models for environmental use that were typical of the industrial society.

In the case of A. Araucana, at the present time remnant populations in Chile and Argentina cover approximately half the area they occupied when the European conquistadors arrived at the beginning of the $16^{\text {th }}$ century (Lara et al. 1999, González et al. 2006). In Argentina, 35\% of these remnant populations are

\footnotetext{
${ }^{1}$ Núcleo de Pesquisas em Florestas Tropicais, Universidade Federal de Santa Catarina, ${ }^{2}$ Laboratório Ecotono, Instituto de Investigaciones en Biodiversidad y Medio Ambiente (INIBIOMA, CONICET-UNCo), ${ }^{3}$ Departamento de Ecologia e Zoologia, Universidade Federal de Santa Catarina
} 
Fig. 1. Distribution ranges of South American Araucaria (Araucaria araucana in Argentina and Chile and $A$. angustifolia in Argentina and Brazil).

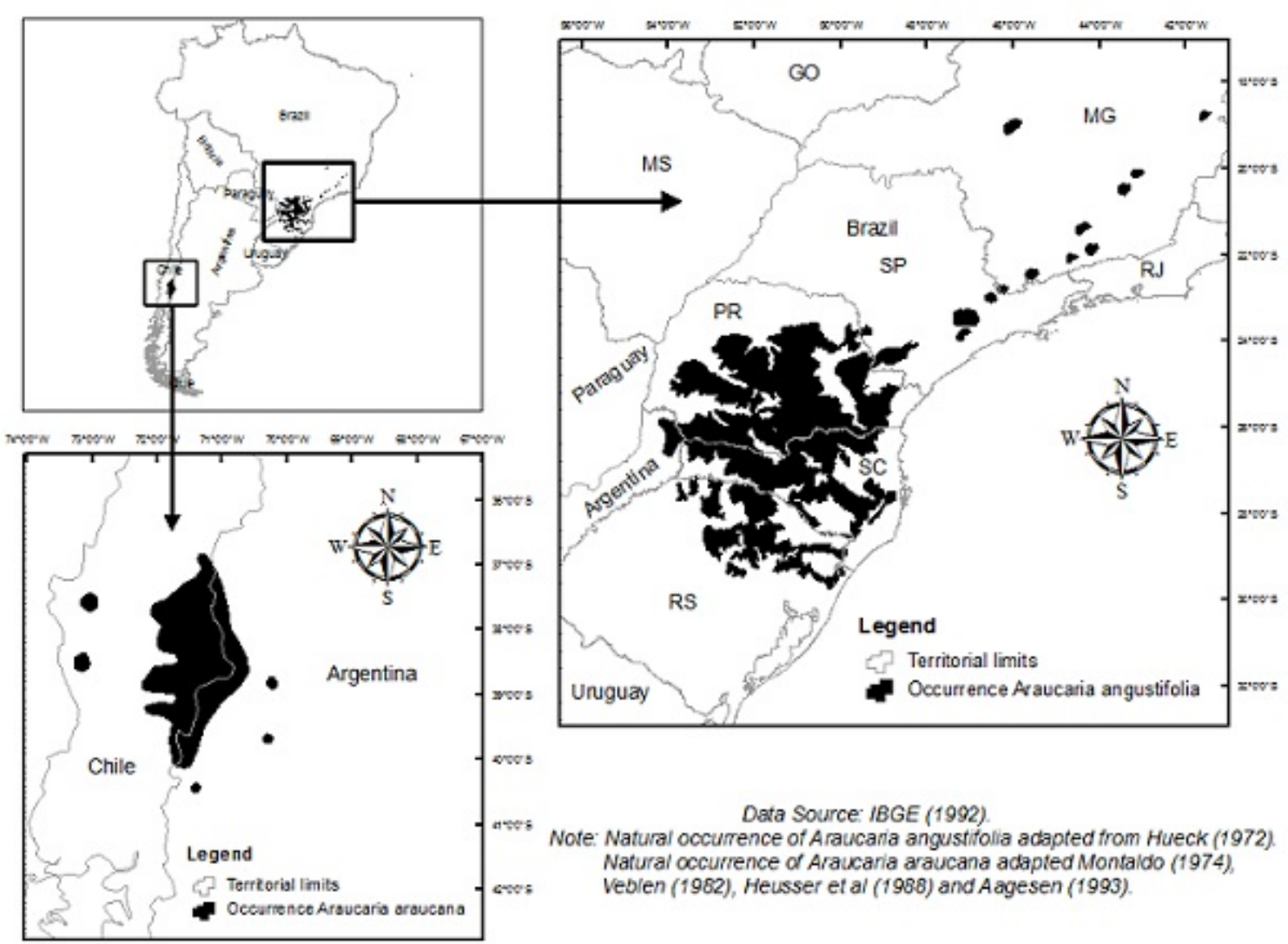

found in protected areas (Lanin National Park and provincial reserves), but parts of them are degraded or threatened (Sanguinetti 2008). In Chile, according to Aagesen (1993) and González et al. (2006), 50\% of the species' distribution is protected in various conservation units, and in 1976 it was declared a natural monument. Nevertheless, these remnant populations are also seriously degraded and/or threatened, with high levels of fragmentation (Zamorano et al. 2008).

The situation for $A$. angustifolia is even more serious, as remnant populations are estimated to cover only between 5\% (Guerra et al. 2002, Castella and Britez 2004) and 12\% (Ribeiro et al. 2009) of the area they covered at the arrival of the European conquistadors at the beginning of the $16^{\text {th }}$ century. Furthermore, according to Vibrans et al. (2011), these remnant populations are found in areas with high levels of degradation and fragmentation. Although the species is present in 72 conservation units, this represents only $0.62 \%$ of their distribution area (Indrusiak and Monteiro 2009). In consideration of this serious situation, several national and international groups in the countries involved have included these two species on different lists of threatened species (e.g., Convention on International Trade in Endangered Species of Flora and Fauna [CITES], IUCN Red List of Threatened Species, etc.; Oldfield et al. 1998).

The state of conservation of both species at the present time can be attributed mainly to their history of human use, influenced by socioeconomic and geopolitical factors. Nevertheless, since the creation of conservation units within their distribution areas, the role of the conservationist paradigm has had a marked influence on the preservation of this and other tree species (Santos Fita el al. 2009, Macura et al. 2011). The prevailing models of biodiversity conservation from the middle of the last century to the beginning of the $21^{\text {st }}$ century consider that protection alone is effective in protected areas (conservation units) and, in the majority of cases, that care of the environment is only possible with the exclusion of human populations from these areas. Paradoxically, in these models, historical (and/or prehistoric) patterns of human occupation and resource use are not contemplated (Berkes and Davidson-Hunt 2006, Clement and Junqueira 2010, Torri and Hermann 2010). This point of view has led to erroneous interpretations of ecosystems, because they do not take into account the role of ancestral human communities in the construction of these landscapes. It has been shown that examples of landscapes considered by science to be "natural" are, in reality, the product of human activity over hundreds or thousands of years, an example being the emblematic case of the Amazon rainforest (Denevan 1992, Woods et al. 2009, Clement and Junquiera 2010, Clement et al. 2010, Shepard and Ramirez 2011), but this is also the case in other regions that are subject to both wet and arid conditions (Denevan 2001, Mercuri 2008, Assis et al. 2010, Capparelli et al. 2011). 
In this context, it seems clear that there is a need to understand interactions between cultures and their environment, the influence of human populations on the construction of different landscapes around the world, and how these relationships alter or maintain the biodiversity and resources of interest to them (Davidson-Hunt and Berkes 2003, Toupal 2003, Berkes and Davidson-Hunt 2006, Torri and Hermann 2010). This approach is based on the idea that the landscape must acquire a dimension of cultural phenomenon for researchers and conservation managers, where the biophysical space, in this case, Araucaria forests, is a product of the history of human societies and reflects the uses, values, learning and the particular cosmovisions of the societies that have used it (Caparelli et al. 2011, Prober et al. 2011). In other words, the landscapes are ecological-cultural (or biocultural) systems that are historically determined and are consequently cultural landscapes (Berkes et al. 2000, Berkes and Folke 2002, Xu et al. 2005, Berkes and Turner 2006, Ladio 2011a).

South American Araucaria forests constitute an interesting study model because they allow the comparison of two very different ecological-cultural systems where a strong interaction with human societies has existed since pre-Colombian times. An analysis of both the ecological and cultural characteristics of the species in this coupled system is thus essential for completely understanding the similarities and differences. In addition to this, the comparison of a temperate-cold $A$ araucana forest with low species diversity (Burns 1991, Veblen et al. 1995) and a subtropical A. angustifolia forest with high diversity (Klein 1978, Reis 1993), both having been inhabited by traditional societies that were highly dependent on their seeds, constitutes an ideal scenario for us to discern convergences in cultural practices and the influence of these practices on the formation of the Araucaria forests.

Therefore, in our work, we analyzed and compared ecological and cultural evidence to help us understand and reflect on the construction of the landscape of $A$. angustifolia and $A$. araucana forests over time, and the role played by human societies in this process. Our three principle guiding questions were: (1) What is the historical path of the coexistence of these forests with human societies?; (2) What ecological characteristics of both species could have been key to the human interest and development of human-forest integration?; and (3) What cultural management practices of human societies could have been relevant in the construction of these landscapes over time?

This perspective on cultural landscapes has rarely been contemplated to date, particularly in terms of the importance of local cultures (past and present) as diversifiers and generators of the plant life in their surroundings (Torri and Hermann 2010, Shepard and Ramirez 2011, Caparelli et al. 2011). This comparative approach lays down a base for more extensive regional comparisons of the role of humans in the history of the world's forests, considering the extent to which people project culture onto their surroundings, thus transforming them into a cultural landscape.

\section{MATERIALS AND METHODS}

Our methodology is based on an exhaustive interdisciplinary bibliographical analysis involving a wide range of sources in the fields of ecological and social science. The bibliographical revision was performed during 2011 and 2012, using the following databases: $\underline{\text { Scielo, }} \underline{\text { Scopus, }}$, and Scirus, using the names of both species as the key words. In addition, a systematic search was carried out of theses, books, book chapters, and old articles from Argentinian, Chilean, Brazilian, and other international journals not available online. A survey of $>100$ references was completed in the following disciplines: paleopalynology, paleobotany, paleoecology, autoecology, community ecology, historical ecology, archaeobotany, archaeology, ethnohistory, and ethnobotany. Given the varied nature of the information in terms of the kind of data and its epistemological approach, data analysis was descriptive-interpretative, putting emphasis on repeated patterns and on the particular characteristics that influenced the differential conformation of the landscapes (Albuquerque et al. 2010, Bernard and Ryan 2010).

\section{RESULTS AND DISCUSSION}

\section{Temporal coexistence of $\boldsymbol{A}$. araucana and $\boldsymbol{A}$. angustifolia with human groups}

Table 1 presents a synthesis of the main evidence for the temporal coexistence of the two Araucaria species with human groups since the Holocene. Although the information obtained is fragmentary, the periods of expansion from Pleistocene refugia and coexistence with human groups has been described. At the end of the Holocene in Brazil, southern Chile, and the northeast and south of Argentina, groups of hunter-gatherers lived in and used the Araucaria forests. The paleopalynological evidence for both species suggests expansion of the distribution area, reaching a maximum in approximately $3000 \mathrm{BP}$ for A. araucana (Heusser et al. 1988, Rondanely-Reyes 2000, Villagrán 2001) and between 1500 and 800 for A. angustifolia (Behling et al. 2001, 2004, Iriarte and Beling 2007, Behling and Pillar 2007, Bauerman et al. 2008, Bitencourt and Krauspenhar 2006; Table 1). Archaeological evidence indicates the presence of human groups, based on signs of fire and/or artifacts found, with repeated occupations previous to this expansion maximum for both species: $4000 \mathrm{BP}$ for $A$. araucana (Adán et al. 2004) and 2500 BP for A. angustifolia (Noelli 2000; Table 1). It is noteworthy that the distribution of $A$. angustifolia forests corresponds closely to the findings of artifacts and subterranean dwellings, that is, "pit houses," "Indian houses," or "Indian holes" of pre-Columbian indigenous groups belonging to the Jê linguistic stock, such as the Kaingang (Noelli 2000, Bitencourt and Krauspenhar 2006, Schmitz 2009). These findings have been interpreted by various authors as evidence that these cultural groups played an important role in the expansion of $A$. angustifolia from the Pleistocene refugia until the occurrence area described by naturalists (Reitz and Klein 1966, Hueck 1972, Mattos 1994) remained stable, in approximately in 100 BP (Table 1). In the case of $A$. araucana, no specific information was found on the period of maximum expansion of the species and its link with human presence but, from the descriptions of Mariño de Lovera (1865), Cox (2006), and Musters (2007), the geographical distribution following the expansion remains stable until $100 \mathrm{BP}$, in coexistence with human groups.

Key ecological characteristics of $\boldsymbol{A}$. araucana and $\boldsymbol{A}$. angustifolia for the development of human-forest integration

An analysis of the available ecological information indicates four factors, convergent in the two species, which have been key to the development of a culture-forest interrelationship. These are: (1) high seed productivity, which is attractive for food and hunting, (2) adaptability to a wide range of environments, (3) regeneration in open environments, and (4) barochoric dispersion (dispersion by gravity). 
Table 1. Evidence of the development over time of the distribution ranges of South American Araucaria from Pleistocene refugia (PR) and their relationship with the presence of human groups (HG) from the Holocene on.

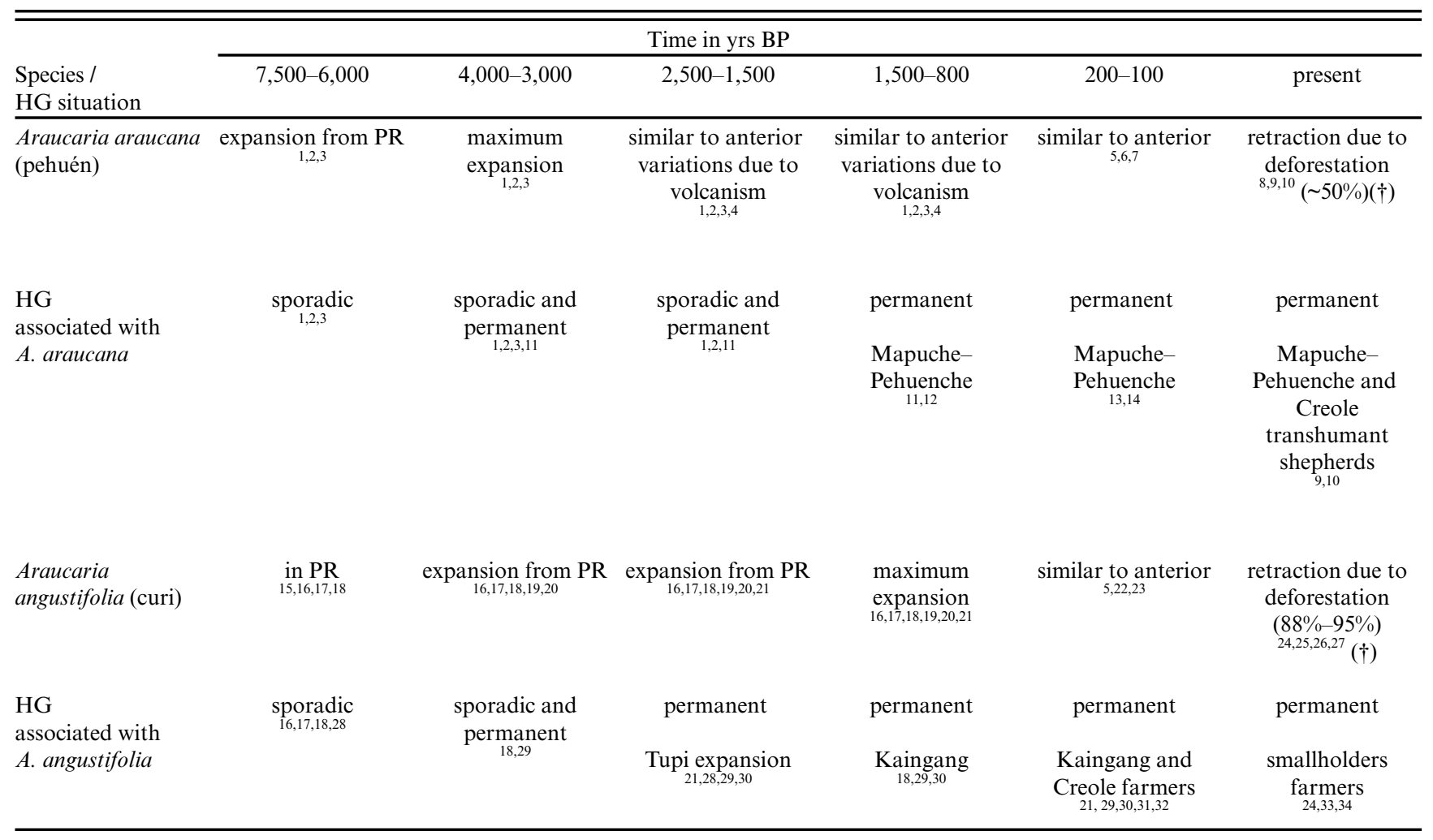

†reation of conservation units

(1) Heusser et al. 1988; (2) Rondaneli-Reyes 2000; (3) Villagrán 2001; (4) Rondanelli-Reyes 2001; (5) Hueck 1972; (6) Veblen et al. 1995; (7) Montaldo 1974; (8) Echeverria et al. 2004; (9) Gonzales et al. 2006; (10) Parque Nacional Lanín 2011; (11) Adán et al. 2004; (12) Mariño de Lovera 1865; (13) Cox 2006; (14) Musters 2007; (15) Kershaw and Wagstaff 2001; (16) Behling et al. 2001; (17) Behling et al. 2004; (18) Iriarte and Beling 2007; (19) Behling and Pillar 2007; (20) Bauerman et al. 2008; (21) Bitencourt and Krauspenhar 2006; (22) Reitz and Klein 1966; (23) Mattos 1994; (24) Guerra et al. 2002; (25) Castella and Benitez 2004; (26) Ribeiro et al. 2009; (27) Indrusiak and Monteiro 2009; (28) Noelli 2008; (29) Noelli 2000; (30) Schmitz 2009; (31) Santos 1973; (32) Becker 1976; (33) Thomé 1995; (34) Vieira da Silva et al. 2011

\section{High seed productivity}

Both species produce a relatively high number of seeds. $A$. araucana can produce an average of $45-50$ cones/tree in years of good production, and even reaching over 300 cones (Parque Nacional Lanin 2011). In moderately good years, the average number of cones/tree found was between 10-20. Average production of seeds/ha is over $600 \mathrm{~kg}$ in years of high productivity, and even passes the $1000 \mathrm{~kg} / \mathrm{ha}$ mark in some stands; in years of moderate production, average productivity is $164 \mathrm{~kg} / \mathrm{ha}$ (Parque Nacional Lanín 2011). For A. angustifolia, estimates obtained from populations inside conservation units vary from six (Vieira da Silva and Reis 2009) to 20 cones/tree (Mantovani et al. 2004), but there are records of up to 46 (Solarzano Filho 2001). In terms of productivity, average estimates for $A$. angustifolia can reach up to $427 \mathrm{~kg} / \mathrm{ha}$ (Solazano Filho 2001), with notable variations between years (117 and $160 \mathrm{~kg} / \mathrm{ha}$, in the same area; Montavoni et al. 2004). Furthermore, in both cases the seeds are relatively large. For $A$. angustifolia, average values lie between $6.2 \mathrm{~g}$ (Zechini et al 2012) and $7.0 \mathrm{~g}$ (Mantovani et al. 2004). For A. araucana, average values registered lie between $3.5 \mathrm{~g}$ (Montaldo 1974) and $4.0 \mathrm{~g}$ (Gonzalez et al. 2006). Therefore, for prehistoric societies with a hunter-gatherer profile such as the Mapuche-Peuenche (Aagensen 1993), or hunter-gatherers with incipient agriculture like the Kaingang (Noelli 2000, Schmitz 2009), these large seeds produced in areas of high productivity would be exceedingly attractive for collection, and the corresponding environment would likely be favorable for hunting, given that animals would also be attracted by the seeds.

\section{Adaptability}

Both species demonstrate wide adaptability to different environments, which enabled them to occupy many new sites that would have been available primarily following climatic changes at the beginning of the Holocene (Table 1). For example, A. araucana inhabits a wide precipitation gradient, which can extend from an annual value of $4000 \mathrm{~mm}$ to $900 \mathrm{~mm}$ (Veblen et al. 1995). It coexists with different formations of temperate-cold forests (associated with Nothofagus antarctica, N. dombeyi, N. pumilio, $N$. nervosa, and also with the conifer Austrocedrus chilensis), and even the Patagonian steppe, with almost pure formations (Burns 1991, Veblen et al. 1995, González et al. 2006). It adapts to sites with shallow soil; in deeper soil, its general competitiveness is lower (Veblen 1982, Burns 1991). A. angustifolia also occupies a 
wide variety of environments, including forests that are rich in species (i.e., >200 tree species; Reis 1993) and forests which are nearly monospecific (Reitz and Klein 1966). It is adapted to subtropical regions as well as temperate, and even sites with occasional snowfalls (Mattos 1994). It grows in sites with deep soil and environments with very superficial soil (Reitz and Klein 1966, Puchalski et al. 2006). It has adapted to different ecological communities, such as understory where Lauraceae species and yerba-mate (Ilex paraguariensis) are dominant and understory where Myrtaceae are dominant, and other associations, including natural grasslands, where it forms dense groups (Reitz and Klein 1966, Klein 1978, Mattos 1994). Therefore, the adaptability of the two species to a very wide range of environments coincides with the adaptability of human populations to live in different scenarios (Baker 1984), an attribute that would facilitate greater coordination and cohesiveness in the human-Araucaria relationship.

\section{Regeneration}

Both species respond well to disturbance and are regenerated in open landscapes. A. araucana is a species that responds well to disturbance and is regenerated in open landscapes (such as the steppe), but also tolerates shade in the initial stages of development (Burns 1991). Therefore, it can germinate and undergo the first stages of development beneath the tree canopy (including the "parent plant") or become established in the clearings formed by fallen trees, a common phenomenon in temperate forests dominated by Nothofagus, where open spaces are frequently formed (Burns 1991). Another important characteristic of the species is its resistance to forest fires (Veblen et al. 1995, González et al. 2006). Adult specimens withstand both fire and volcanic activity given their thick bark (Veblen et al. 1995, González et al. 2006), and so can initiate colonization in disturbed environments, an important advantage over other tree species like Nothofagus (Burns 1991). In altered sites, this strategy seems to be particularly linked to their vegetative propagation capacity, via resprouting roots and stumps (Burns 1991, Veblen et al. 1995, González et al. 2006). The dynamics of regeneration associated with disturbance, including clearances produced by fallen trees of other species, fire and volcanic activity, is of particular importance. This is because it increases competitiveness and the likelihood of persistence over time of A. araucana populations in comparison with other forest species. These advantageous characteristics must have been influential in the increase of the occurrence area and density of $A$. araucana. Studies indicate the presence of humans over 3000 yrs ago (see Table 1), with the probable use of disturbances such as fire for hunting and the consumption of toasted piñones, as discussed by Aegensen (2004) and Veblen et al. (2008). These human interventions, which have taken advantage of the successional dynamics of the species, may have fostered a process that was to mutual advantage, increasing opportunities for the development of pehuén forests and increasing the availability of food for the human groups associated with this environment. Aspects related to the regeneration of $A$. angustifolia are similar to those described for $A$. araucana, and their recruitment is also dependent on large clearings (Puchalsky et al. 2006). This species regenerates in open spaces, especially in grasslands and in forest clearings (Reitz and Klein 1966, Caldato et al. 1996, Duarte et al. 2002, Narvaes et al. 2005, Souza et al. 2008, Dillenburg et al. 2009), but is tolerant of shade in the initial stages of development (Dillenburg et al. 2009). In contrast to the pehuén, A. angustifolia depends almost exclusively on seeds for regeneration. In addition, adult trees can also tolerate fire, particularly in grassland environments (Reitz and Klein 1966, Mattos 1994). Although forest fires are currently uncommon in areas where A. angustifolia occur, palynological studies show that there was a time when fire was more frequent, mainly during the $A$. angustifolia forest expansion period (Behling and Pillar 2007, Bauermann et al. 2008). The same authors associate the existence of grasslands with the management practices of fire used by human groups in the Holocene. Palaeoethnobotanical evidence, especially that mentioned by Noelli (2000) and Schmitz (2009), reinforces this association. Once again, human practices appear to have played an important role in the expansion and formation of Araucaria forests, increasing opportunities for regeneration of the species and, thereby, increasing the availability of part of their food supply.

\section{Barochoric dispersion}

Barochory is the first, and the principal, mechanism of seed dispersal in both species (Reitz and Klein 1966, Montaldo 1974, Mattos 1994, Mantovani et al. 2004, Sanguinetti 2008, Shepard et al. 2008, Vieira and Iob 2009, Shepard and Ditgen 2012). The heavy, poorly dispersed seeds constitute an additional factor that facilitates collection of a large quantity of resources with little effort. However, this mechanism is significantly limiting in terms of the rhythm of expansion of both species. Long-distance animal dispersion (primary and secondary) has been characterized for A. araucana (Gonzalez et al. 2006, Shephard et al. 2008, Saguinetti 2008, Shephard and Ditgen 2012) and for A. angustifolia (Solarzano Filho 2001, Vieira and Iob 2009), but in both cases as a sporadic, low-frequency occurrence. Therefore, the action of prehistoric human groups associated with the Araucaria forests would increase the likelihood of longer distance dispersion, favoring the expansion of Araucaria populations, particularly given the aforementioned capacity for adaptation to a wide range of environments. This has been suggested by various authors for A. angustifolia (Noelli 2000, Bitencourt and Krauspenhar 2006, Schmitz 2009, Klabunde 2012) and for A. araucana, but in a nonintentional and/or sporadic manner (Veblen 1982, Burns 1991, Veblen et al. 1995, Ruiz et al. 2007, Marchelli et al. 2009). In neither case has this question been studied in depth.

One additional piece of evidence in this context is the lack of isolation by distance in all the genetic studies in both species (Auller et al. 2002, Bekessy et al. 2002, Ruiz et al. 2007, Stefenon et al. 2008, Machielli et al. 2009, Reis et al. 2012, Klabunde 2012). In addition, the genetic studies show elevated values of the fixation index $\left(F\right.$ or $F_{\text {IS }}$ ) for several populations (Auller et al. 2002, Gallo et al. 2004, Ruiz et al. 2007, Ferreira et al. 2011, Reis et al. 2012), unexpected in diocious species. Considering all ecological characteristics, these results reinforce the possibility of the establishment of several new populations attributed to human displacement and migrations. Obviously, recent forest exploitation and fragmentation has led to a loss of diversity and an increase in fixation indices, but a high level of kinship and foundational effects can also produce high values for these indices. Thus, populations derived from seeds that came from the same tree, or few trees, may present a high level of kinship among its individuals and, therefore, elevated levels of fixation indexes $(\mathrm{F})$. This evidence, associated with the longevity of individuals, is 
compatible with the practices used by early human populations, creating conditions (intentionally or otherwise) favorable to the formation of new populations.

These ecological characteristics of A. araucana and A. angustifolia have been recognized and taken advantage of by local cultures in such a way that, with wide knowledge of the production of available food and its phenology, they have adjusted their dwelling places and patterns of movement in harmony with the season of seed production (Ladio and Lozada 2004a, Bitencourt and Krauspenhar 2006, Schmitz 2009). Theoretical models in archaeology consider the forests to be highly dependable environments, as their productivity is predictable for human populations (Gamble 1990). All these shared characteristics have, without a doubt, favored a coupling typical of a biocultural system.

\section{Cultural practices and the management of cultural landscapes with Araucaria}

Since prehistoric times, the South American Araucaria forests have constituted a staple food resource (Noelli 2000, Ladio 2011a). Table 2 shows a summary of the main ethnohistorical and ethnobotanical evidence for the human practices and uses associated with the Araucaria, which show a notable level of convergence. In both cases, reference is made to procedures for the production of flour, bread, beverages, etc., as well as similar storage systems (Table 2). For both species, there are also records of other current uses, such as firewood, medicines, and fodder (Table 2).

In the case of $A$. araucana, the practice of gathering piñones is culturally very important. Specific ethnic terms are used to describe it: "ngümitun" or "piñoneo," and it is distinguished linguistically from the gathering of other plants (Ladio 2011b). This practice generally takes place between February and April, when the mature piñones fall from the cones on the trees (Aagensen 1998, Herrmann 2005). At the present time, the piñoneo is not only carried out by the inhabitants of Araucaria forests, but also by Mapuche communities who live far from them. These Mapuche communities live in the more steppe-like areas to the east of the Andes and, therefore, have adapted their traditional livestock breeding practices (their main means of making a living) to a multiple use of the environment along with the piñoneo. Thus, families tend to move toward the forest in the summer to take better advantage of the grasslands, establishing semipermanent dwelling sites in the area, a tradition known as "veranada" or summer pasturing (Aagensen 1998, Ladio and Lozada 2000, Ladio 2001, Ladio and Lozada 2004b, Herrmann 2005). The families stay in the forests until autumn, when, after gathering the piñones, they return to their winter pastures for the rest of the year (Ladio and Lozada 2000). Studies carried out in transhumant Mapuche communities of Neuquén indicate that the veranada, in combination with the piñoneo, is a very efficient adaptive strategy, offering the chance of a tastier, more nutritious diet (Ladio 2001) and diversified use of the environment for grazing, despite the fact that this migration involves distances of $>100 \mathrm{~km}$ (Ladio and Lozada 2000, Ladio 2001). Some of the piñones are consumed, toasted, or cooked during the summer pasturing, but a large proportion ( $>100 \mathrm{~kg}$ per journey) is taken to the winter dwelling site (Ladio and Lozada 2000). In other words, practices for the transport and storage of piñones have existed from prehistoric times to the present as a strategy to extend the period of use and the site of consumption (Aagensen 1993, Ladio and Lozada 2000, Ladio 2001, Herrmann 2005).

As with $A$. Araucana, A. angustifolia forests were used by the Kaingang with marked territoriality (Table 2). The oldest accounts, such as those of Mabilde in the $19^{\text {th }}$ century (studied by Becker 1976), tell of a system of administration of the Araucaria resource, with the use of the pinhões based on family lines and chiefs involved in the administration to guarantee equal sharing amongst the whole tribe. Individual invasion of the gathering territory was punishable by death, and collective invasion was a motive for war between tribes or divisions of a tribe (Becker 1976, Schimtz 2009). During the ripening period of the pinhões, gathering was carried out by the tribes in an organized fashion, following the limits of a territory that was demarcated with specially marked A. angustifolia trees (Becker 1976, Klanovicz 2009, Schmitz 2009). The men would climb the trees and knock down the cones, and the women gathered up the cones and pinhões; in contrast to A. araucana, whole cones were gathered. Following collection, some pinhões were consumed directly, toasted, or cooked, but most were transported and stored in special containers in a humid environment (such as in streams) for varying time periods (for months, if necessary), depending on the future destiny of the pinhões, i.e., direct consumption or flour production (Schmitz 2009).

The ethnohistorical and ethnobotanical evidence is particularly relevant for demonstrating that both species hold strong cultural and symbolic significance for the people that have coexisted with them (Table 2). The relationship between the Mapuche and $A$. araucana has been so close that the societies that used them called themselves, in their language (Mapuzungun), "Pehuenche," or people ("che") of the pehuén (A. araucana; Aagensen 1993, Ladio 2001, Herrmann 2005). In the Mapuche cosmology, the development and architecture of their trees is associated with the development of families within the community. According to Aagensen (2004) and Herrmann (2005), for the Pehuenche, the development of a forest begins with the contact of the roots of masculine and feminine plants, forming the new plants and protecting the families of the Pehuenche people. Therefore, to the Pehuenche, the pehuén is a sacred plant, created by one of the gods ("gwenachen") to feed his sons. This strong significance is renewed and reaffirmed annually with festivals dedicated to $A$. araucana, called "ngillatun" (Herrmann 2005). In this traditional ceremony, thanks are given for the "ngulliw" (piñones) and they are celebrated with offerings, prayers, and songs that are still carried out today in both Chile and Argentina (Aagensen 1993, Herrmann 2005). This cosmovision testifies that the landscape of the pehuén is perceived culturally as a biocultural unit, involving not only a utilitarian relationship but also a symbolic and religious one with these forests that date from the very beginnings of this society.

It is also noteworthy that, at the present time, in the case of Mapuche populations who live in pehuén forests, part of the piñon crop is sold to obtain monetary resources (Table 2). In contrast, this practice is not common amongst the Mapuche who live far from the forests (Aagensen 1993, Ladio 2001, Azócar et al. 2005, Herrmann 2006, Sanguinetti 2008, Parque Nacional Lanín 2011). The trend toward increased commercialization of piñones and 
Table 2. Ethnohistorical evidence and current cultural practices and uses associated with the South American Araucaria species.

\begin{tabular}{|c|c|c|c|c|}
\hline \multirow[b]{2}{*}{ Cultural practices } & \multicolumn{2}{|c|}{ Araucaria araucana } & \multicolumn{2}{|c|}{ Araucaria angustifolia } \\
\hline & $\begin{array}{c}\text { Ethnohistorical } \\
\text { evidence }\end{array}$ & Current evidence & Ethnohistorical evidence & Current evidence \\
\hline Staple food & $\begin{array}{c}\text { piñones }^{\dagger} \text { for Mapuche- } \\
\text { Pehuenches } \\
1,2,3,4,5,6,7\end{array}$ & $\begin{array}{c}\text { piñones }^{\dagger} \text { for Mapuche- } \\
\text { Pehuenches } \\
2,3,4,5,6,8\end{array}$ & pinhões $^{\dagger}$ for Kaingangs & $\begin{array}{c}\text { pinhões }^{\dagger} \text { for smallholders } \\
\text { farmers } \\
12,13,14\end{array}$ \\
\hline Gathering & $\begin{array}{c}\text { family } \\
\text { piñoneo/ngümitun } \\
\text { associated with } \\
\text { transhumance } \\
1,2,3,4,5,6,7\end{array}$ & $\begin{array}{c}\text { family } \\
\text { piñoneo/ngümitun } \\
\text { associated with sheep } \\
\text { transhumance } \\
2,3,4,5,6,8,15,16\end{array}$ & family & $\underset{12,13,14,18,19}{\text { family }}$ \\
\hline Transport & long distances & $\operatorname{long~distances~}_{3,4,5,8,16}$ & $\begin{array}{c}\text { in specific containers } \\
\text { (baskets); distances not } \\
\text { defined } \\
9,11\end{array}$ & $\underset{12,13,14,18,19}{\operatorname{long} \text { distances }}$ \\
\hline \multirow[t]{2}{*}{$\begin{array}{l}\text { Processing and } \\
\text { cooking }\end{array}$} & $\begin{array}{l}\text { flour, bread, beverages } \\
\text { (mudai) } \\
1,3,5,6\end{array}$ & $\begin{array}{c}\text { flour, bread, beverages } \\
\text { (mudai), soups, fillings, } \\
\text { sweets } \\
3,4,5,8\end{array}$ & $\underset{9,11}{\text { flour, bread }}$ & $\begin{array}{l}\text { flour, bread, sweets } \\
\text { culinary diversification for sale } \\
\text { and added value }\end{array}$ \\
\hline & & $\begin{array}{l}\text { incipient culinary } \\
\text { diversification }\end{array}$ & & \\
\hline Storage & $\begin{array}{c}\text { buried in damp locations } \\
\text { (mallines and vegetable } \\
\text { gardens) } \\
3,5,6,8\end{array}$ & $\begin{array}{c}\text { buried in damp locations } \\
\text { (mallines and vegetable } \\
\text { gardens) } \\
\text { dry storage } \\
3,5,6,8\end{array}$ & $\begin{array}{l}\text { buried in damp locations } \\
\text { and in river beds } \\
9,11\end{array}$ & $\begin{array}{l}\text { dry storage and as a processed } \\
\text { product } \\
13,14\end{array}$ \\
\hline \multirow[t]{2}{*}{$\begin{array}{l}\text { Cosmology and } \\
\text { cultural identity }\end{array}$} & sacred plant & sacred plant & no data & $\begin{array}{l}\text { cultural identification } \\
\text { traditional regional celebrations }\end{array}$ \\
\hline & $\begin{array}{c}\text { Mapuche-Pehuenche } \\
\text { cultural identification } \\
\text { rites and symbolism } \\
\text { Thanksgiving festival } \\
1,2,3,4,5,6,8\end{array}$ & $\begin{array}{l}\text { Mapuche-Pehuenche } \\
\text { cultural identification } \\
\text { rites and symbolism } \\
\text { Thanksgiving festival and } \\
\text { traditional regional } \\
\quad \text { celebration } \\
\text { 2,3,3,5,6,8,16}\end{array}$ & & \\
\hline Territoriality & $\begin{array}{l}\text { social control of the } \\
\text { community and } \\
\text { territoriality by family } \\
\text { lineage } \\
20\end{array}$ & $\begin{array}{l}\text { social control of the } \\
\text { community and territoriality } \\
\text { by family lineage } \\
\text { control of private property } \\
2,15,16\end{array}$ & $\begin{array}{l}\text { social control of the } \\
\text { community and } \\
\text { territoriality by family } \\
\text { lineage } \\
\text { marked trees } \\
9,10,11,17,21\end{array}$ & control of private property \\
\hline Other uses & $\begin{array}{l}\text { firewood, medicine, fodder, } \\
\text { trees used as signposts }\end{array}$ & $\begin{array}{c}\text { firewood, medicine, fodder, } \\
\text { lumber, product for exchange } \\
\text { or sale } \\
3,4,5,6,8,15,16\end{array}$ & $\begin{array}{c}\text { firewood, fodder, } \\
\text { hunting environment }\end{array}$ & $\begin{array}{l}\text { firewood, medicine, fodder, } \\
\text { lumber, product for sale }\end{array}$ \\
\hline \multicolumn{5}{|c|}{$\begin{array}{l}\text { Local name for nut-like seeds. } \\
\text { Local name for the practice in the Mapuzumgun language. } \\
\text { Local name for wetland meadow in the Mapuzumgun language. } \\
\text { (1) Montaldo 1974; (2) Aagesen 1998; (3) Ladio 2000; (4) Aagensen 2004; (5) Herrmann 2005; (6) Herrmann 2006; (7) Musters 2007; (8) Ladio and } \\
\text { Lozada 2001; (9) Noelli 2000; (10) Bitencourt and Krauspenhar 2006; (11)Schmitz 2009; (12) Guerra et al. 2002; (13) Vieira da Silva and Reis 2009; } \\
\text { (14) Vieira da Silva et al. 2011; (15) Parque Nacional Lananín 2011; (16) Ladio 2011a; (17) Becker 1976; (18) Schuster and Lowen-Shar 2009; (19) } \\
\text { Assis et al. 2010; (20) Jaña 1997; (21) Klanovicz 2009; (22) Dimitri 1972 }\end{array}$} \\
\hline
\end{tabular}


less use in terms of direct self-sufficiency has been recorded in recent years as a worrying situation for the regeneration of the species (Sanguinetti 2008, Parque Nacional Lanin 2011).

Various authors have suggested the importance of anthropic action in the past, and specifically that of abandoning seeds in sites associated with communication routes used by indigenous peoples and/or their intentional cultivation (Dimitri 1972, Hajduk personal communication). The existence of current management practices favoring the maintenance of $A$. araucana populations has also been documented by Herrmann (2005, 2006), such as planting seeds during the piñoneo at the gathering sites themselves. This enhancement has led to a direct increase in pehuén population density. In addition, we documented (but not quantitatively) other in situ management practices in pehuén forests, such as trees that are deliberately left standing when the vegetation is disturbed (road or house construction), and the direct protection of desirable pehuén trees against sociocultural and environmental factors endangering their permanence.

Ladio and Lozada (2000) showed that Mapuche families that live outside the occurrence area (up to $100 \mathrm{~km}$ ) collect and transport $>100 \mathrm{~kg}$ of pehuén seeds per gathering trip. Handling this large volume of seeds leads to many being dropped along the way, as the people who live outside the occurrence area undertake the long journey home on horseback. Moreover, seeds are preserved in sacks buried underground in mallines (flood meadows) or gardens near their homes, where some seeds germinate spontaneously, according to some informants, and are protected by the family in the new context (Ladio, personal observation). In addition, trees growing ex situ, and managed outside pehuén natural environments through seed sowing or the transplantation of young plants were also noted in some Mapuche populations.

This type of management occurs at varying levels of intensity and must be studied and quantified in more detail; however, different, simultaneous routes of interconnection can be seen. The habit of intentional cultivation by the Mapuche seen at the present time, associated with long distances for the transport of piñones described since prehistoric times, could be a key factor in the understanding of human influence in the spatial distribution of the species. This is related in particular to the ecological aspects mentioned in Table 2, reinforcing evidence of a human role in the expansion of Araucaria araucana forests.

For A. angustifolia, no references were found relating to an associated cosmology, but there are records of the cultural importance of pinhões to the aborigines who inhabited the south of Brazil, particularly the Kaingang and Xokleng (Santos 1973, Thomé 1995, Vieira 2004, Bitencout and Krauspenhar 2006, Klanovicz 2009, Schmitz 2009). The scarcity of documentation is directly related to the fact that these peoples were decimated both during and following contact with the European conquistadors, thus leaving a gap in our knowledge of their cultural heritage.

Following the Tupi expansion, around 2500 years BP (Noelli 2000, 2008), aborigines from the Jê linguistic stock, who were inhabitants of "underground dwellings," occupied the central region of the south of Brazil (Bitencourt and Krauspenhar 2006, Schmitz 2009). However, no accounts relating to specific practices employed during this period have been found. These groups, considered hunter-gatherers, gave origin to the Kaingang, a group that was strongly dependent on forest resources, combined with agriculture in small forest clearings (Noelli 2000, Schmitz 2009).

Following the arrival of the European conquistadors in the $16^{\text {th }}$ century, there was a period of reduced human occupation in the A. angustifolia forests, mostly in the forests of southern Brazil (Noelli 2000). Until the $19^{\text {th }}$ century, they were present mainly in the coastal area and grasslands, environments used extensively for rearing livestock (Dean 1996). As a result, until the $19^{\text {th }}$ century, some of the knowledge and practices relating to the management of $A$. angustifolia was transferred from the indigenous peoples to other dwellers on the lands, who adopted similar practices of use, gathering, and preservation of pinhões, as well as cultivation (in small clearings). In contrast, during the first half of the $20^{\text {th }}$ century, there was a strong move toward forest exploitation and the colonization of European immigrants throughout the area inhabited by A. angustifolia (Thomé 1995, Dean 1996, Carvalho 2006). From the end of the $19^{\text {th }}$ century and first half of the $20^{\text {th }}$ century, the remaining aborigines were decimated or shut into restricted indigenous reserves in the name of the new "colonization" (Santos 1973, Thomé 1995), but contrary to the case of the Mapuche and A. araucana, they were not thrown out of their territories for conservation reasons. During this period, the cultural perception of $A$. angustifolia became exclusively that of a lumber resource (Carvalho 2006). At the present time, much knowledge of the traditional practices of management used by the Kaingang in the Araucaria forests, as well as their techniques for the use and preservation of the pinhões, has been lost or is maintained only in some indigenous reserves (Peroni, personal observation). Nevertheless, smallholders, descendants of the first settlers and the new European immigrants, continued the use of pinhões for consumption or animal fodder, even adapting systems of management such as the "faxinais" and the "caívas;" both landscapes management systems (cultural landscapes) traditionally used by smallholders for food production that includes Araucaria angustifolia, Ilex paraguarensis (erva-mate), pigs, and/or cattle, and other resources, in a communal (faxinais) or individual area (Schuster and LowenShar 2009, Assis et al. 2010, Reis et al. 2013). In the forest remnants with $A$. angustifolia, farmers gather pinhões for consumption and sale, and also use this resource as fodder for pigs and cattle (Assis et al. 2010). In the case of $A$. angustifolia, at the present time, smallholders transport and sell the pinhões in village or city markets, thus forming a link in a commercial chain that transports pinhões hundreds of kilometers (Vieria da Silva and Reis 2009, Vieira da Silva et al. 2011).

\section{Cultural landscapes with Araucaria and conservation by use practices}

Gathering pinhões currently represents an important source of income for smallholders in the remnant forests of A. angustifolia (Vieira de Silva and Reis 2009, Assis et al. 2010, Zechini et al. 2012). In addition, in recent years there has been a move toward the cultural revaluation and re-significance of A. angustifolia and the pinhões as symbols of a way of life that values traditions and the environment in the south of Brazil. Government policies revaluing pinhões as a food resource and commercial product have been promoted by various local and regional organizations (Vieira da Silva et al. 2011). Cultural re-signification of $A$. 
araucana forest is also found in Argentina and Chile (Ladio, personal observation, Herrmann 2006, Newton 2008; Table 2). These aspects are generating an increase in the appreciation of landscapes with Araucaria on farm properties, motivating farmers to conserve them.

Recent studies that have measured the impact of piñon gathering by human populations have shown that if the traditional methods are maintained, the regeneration of these two species is not affected (Gallo et al. 2004, Sanguinetti 2008, Reis et al. 2010). In contrast, practices that include the presence of livestock are clearly damaging to the regeneration of both $A$. araucana (Sanguinetti 2008, Parque Nacional Lanín 2011) and $A$. angustifolia (Vibrans et al. 2011).

Local communities possibly recognized the ecological characteristics of both species, particularly their resistance and great capacity for adaptation and regeneration, and so were able to learn how to manage or manipulate the forests according to their cultural and symbolic criteria. The forests were used in compliance with cultural norms that guaranteed their rational, sustainable use. At the present time, the communities that maintain traditional practices in the forests have so far been able to preserve them. This is the case of the country farmers who produce yerba mate in Brazil (Assis et al. 2010, Reis et al. 2010, Vieira da Silva et al. 2011) and the sustainable use of the pehuén in Patagonia (Aegesen 2004, Herrmann 2006, Newton 2008).

In addition to this, current studies have highlighted deficiencies in the natural regeneration of both species in several protected areas (Caldato et al. 1996, Duarte et al. 2002, Narvaes et al. 2005, Puchalsky et al. 2006, Souza et al. 2008. Sanguinetti 2008). In some cases of deficiencies reported in conservation units, the principal reason is the absence of disturbances to create suitable areas for the development of the young plants (Caldato et al. 1996, Narvaes et al. 2005, Souza et al. 2008). Therefore, there is evidence that landscapes with araucaria are under threat even in the conservation units.

\section{FINAL COMMENTS}

This revisionionary work has demonstrated the historical coexistence of traditional societies with $A$. auracana and $A$. angustifolia for $>3000$ years. Despite their extensive distribution areas and their contrasting biogeography, we can see convergence in the intensity of use of these forests by the traditional societies. This intensity is based on the use of the seeds as a staple food source, but also on exhaustive knowledge of the ecological characteristics of each species, and a notable adjustment of cultural practices and management that may have led to a greater level of interconnection. In addition, the culture projected on these forests over a long period of time seems to have favored the creation of two landscapes (A. araucana and A. angustifolia forests) that were molded by their inhabitants. The South American Araucaria landscapes reflect use patterns of both the past and the present, which converge with cultural significance that transcends their merely utilitarian function. In both cases, this system constitutes the most complete expression of a biocultural system.

The evidence supports the idea that the different cultures that have interacted with these forests could have favored their expansion and their abundance in the past. Local communities possibly recognized the ecological characteristics of both species, particularly their resilience and great capacity for adaptation and regeneration, and so have been able to learn to manage or manipulate the forests according to their cultural and symbolic criteria. The forests were used in compliance with cultural norms that guaranteed their rational and sustainable use. The communities that currently maintain traditional in situ and ex situ management practices, by means of tolerance, enhancement, and protection in the occurrence area, and by cultivation of seeds and/ or transplanting trees outside the range, could have been more able to preserve them. In relation to this, various authors (Casas et al. 2001, Blancas et al. 2010, Parra et al. 2012) have also shown the importance of the identification of these practices and their changes over time. In addition, as with other species that were strongly favored by human need, and domesticated in many cases, the absence of active measures could lead to a decline in the population (Clement $1999 a, b)$.

The cultural landscapes approach, which considers the role of societies as modelers of the natural landscape, can offer new perspectives on conservation policies and action with regard to both forests. In this sense, although apparently diametrically opposed to the conservationist paradigm, the conservation of both species could be much more sustainable if traditional use were involved in conservation strategies. Without this human dimension, Araucaria forests probably can be well conserved, but perhaps with different patterns and components, because they will not be modeled on the same traditional criteria, used for procuring food in a sustainable way for present and future generations.

Therefore, it is necessary to identify and reproduce those management practices that help to maintain or increase these resources within and outside of conservation units. A partnership between conservation biologists and traditional communities may be the most successful way to achieve conservation or restoration efforts. This idea clashes with some government measures, frequently used by conservation agencies in Brazil and Argentina, that prohibit or restrict use, ignoring the context, needs, and expectations of the habitual users of the Araucaria forests.

A future line of research arising from this work is the idea of evaluating in more depth, for both species, the hypothesis of domestication, so as to understand how Araucaria landscapes have been constructed in accordance with the style and needs of each culture.

Responses to this article can be read online at: http://www.ecologyandsociety.org/issues/responses. $\mathrm{php} / 6163$

\section{Acknowledgments:}

This study was part of a MSR senior post-doctoral fellowship from CAPES (BEX 8799/11-3). We thank FAPESC for partial financial support and CNPq for productivity research fellowship of MSR. and $N P$. 


\section{LITERATURE CITED}

Aagesen, D. L. 1993. The natural and social geography of Araucaria araucana. Dissertation. University of Minnesota, Minneapolis, Minnesota, USA.

Aagesen, D. L. 1998. Indigenous resource rights and conservation of the monkey-puzzle tree (Araucaria araucana, Araucariaceae): a case study from southern Chile. Economic Botany 52:146-160. http://dx.doi.org/10.1007/BF02861203

Aagesen, D. L. 2004. Burning monkey-puzzle: native fire ecology and forest management in northern Patagonia. Agriculture and Human Values 21:233-242. http://dx.doi.org/10.1023/B: AHUM.0000029402.85972.6c

Adán, L., R. Mera, M. Becerra, and M. Godoy. 2004. Ocupación arcaica en territorios boscosos y lacustres de la región precordillerana andina del centro-sur de Chile: el sitio marifilo-1 de la localidad de Pucura. Revista de Antropología Chilena 36:1121-1136.

Alburquerque, U. P., R. F. Paiva de Lucena, and L. V. F. Cruz da Cunha, editors. 2010. Métodos e técnicas na pesquisa Etnobiológica y Etnoecológica. First edition. NUPPEA, Recife, Pernambuco, Brazil.

Assis, A. L., N. Hanazaki, M. S. Reis, A. G. Mattos, and N. Peroni. 2010. Espécie-chave cultural: indicadores e aplicabilidade em etnoecologia. Pages 145-153 in A. G. C. Alves, F. J. B. Souto, and N. Peroni, editors. Etnoecologia em perspectiva: natureza, cultura e conservação. NUPPEA, Recife, Pernambuco, Brazil.

Auler, N. M. F., M. S. Reis, M. P. Guerra, and R. O. Nodari. 2002. The genetics and conservation of Araucaria angustifolia: I. Genetic structure and diversity of natural populations by means of non-adaptive variation in the state of Santa Catarina, Brazil. Genetics and Molecular Biology 25(3):329-338. http://dx.doi. org/10.1590/S1415-47572002000300014

Azócar, G., R. Sanhueza, M. Aguayo, H. Romero and M. D. Muñoz. 2005. Conflicts for control of Mapuche-Pehuenche land and natural resources in the Biobío highlands, Chile. Journal of Latin American Geography 4(2):57-76. http://dx.doi.org/10.1353/ lag.2005.0035

Bauermann, S. G., R. B. Macedo, H. Behling, V. P. Pillar, and P. C. P. Neves. 2008. Dinâmicas vegetacionais, climáticas e do fogo com base em palinologia e análise multivariada no quaternário tardio do Sul do Brasil. Revista Brasileira de Paleontologia 11 (2):87-96. [online] URL: http://www.sbpbrasil.org/revista/ edicoes/11 2/RBP11-2bauerman.pdf

Baker, P. 1984. The adaptive limits of human populations. Man 19(1):1-14. http://dx.doi.org/10.2307/2803221

Becker, I. I. B. 1976. O índio Kaingang no Rio Grande do Sul. Pesquisas Antropologia 29. Instituto Anchietano de Pesquisas/ Unisinos, São Leopoldo, Rio Grande do Sul, Brazil.

Behling, H. 2007. Late Quaternary vegetation, fire and climate dynamics of Serra do Araçatuba in the Atlantic coastal mountains of Paraná State, southern Brazil. Vegetation History and Archaeobotany 16:77-85. http://dx.doi.org/10.1007/s00334-006-0078-2

Behling, H., S. G. Bauerman, and P. C. Neves. 2001. Holocene environmental changes from São Francisco de Paula region,
Southern Brazil. Journal of South American Earth Sciences 14:631-639. http://dx.doi.org/10.1016/S0895-9811(01)00040-2

Behling H., and V. P. Pillar. 2007. Late Quaternary vegetation, biodiversity and fire dynamics on the southern Brazilian highland and their implication or conservation and management of modern Araucaria forest and grassland ecosystems. Philosophical Transactions of the Royal Society B 362:243-251. http://dx.doi. org/10.1098/rstb.2006.1984

Behling, H., V. P. Pillar, L. Orloci, and S. G. Bauermann. 2004. Late Quaternary Araucaria forest, grassland (campos), fire and climate dynamics, inferred from a high-resolution pollen record of Cambará do Sul in southern Brazil. Palaeogeograph, Palaeoclimatology, Palaeoecology 203:277-297. http://dx.doi. org/10.1016/S0031-0182(03)00687-4

Bekessy, S. A., T. R. Allnutt, A. C. Premoli, A. Lara, R. A. Ennos, M. A. Burgman, M. Cortes, and A. C. Newton. 2002. Genetic variation in the vulnerable and endemic Monkey Puzzle tree, detected using RAPDs. Heredity 88:243-249. http://dx.doi. org/10.1038/sj.hdy. 6800033

Behling, H. 2007. Late quaternary vegetation, fire and climate dynamics of Serra do Araçatuba in the Atlantic coastal mountains of Paraná State, southern Brazil. Vegetation History and Archaeobotany 16:77-85. http://dx.doi.org/10.1007/s00334-006-0078-2

Berkes, F., J. Colding, and C. Folke. 2000. Rediscovery of traditional ecological knowledge as adaptive management. Ecological Applications 10:1251-1262. http://dx.doi.org/10.1890/1051-0761 (2000)010[1251:ROTEKA]2.0.CO;2

Berkes, F., and I. J. Davidson-Hunt. 2006. Biodiversity, traditional management systems, and cultural landscapes: examples from the boreal forest of Canada. International Social Science Journal United Nations Educational, Scientific and Cultural Organization (UNESCO) 58:35-47. http://dx.doi.org/10.1111/ j.1468-2451.2006.00605.X

Berkes, F., and C. Folke. 2002. Back to the future: ecosystem dynamics and local knowledge. Pages 121-146 in L. H. Gunderson and C. S. Holling, editors. Panarchy: understanding transformations in human and natural systems. Island Press, London, UK.

Berkes, F., and N. Turner. 2006. Knowledge, learning and the resilience of social-ecological systems. Human Ecology 34:479494. http://dx.doi.org/10.1007/s10745-006-9008-2

Bernard, H. R., and G. W. Ryan. 2010. Analyzing qualitative data: systematic approaches. Sage, London, UK.

Bitencourt, A. L. V., and P. M. Krauspenhar. 2006. Possible prehistoric anthropogenic effect on Araucaria angustifolia (Bert.) O. Kuntze expansion during the late Holocene. Revista Brasileira de Paleontologia 9:109-116. [online] URL: http://sbpbrasil.org/ revista/edicoes/9 1/Bitencourt.pdf

Blancas, J., A. Casas, S. Rangel-Landa, A. Moreno-Calles, I. Torres, E. Pérez-Negrón, L. Solis, A. Delgado-Lemus, F. Parra, Y. Arellanes, J. Caballero, L. Cortes, R. Lira, and P. D' Avila. 2010. Plant management in the Tehuacán-Cuicatlán Valley, Mexico. Economic Botany 64(4):287-302. http://dx.doi.org/ 10.1007/ $\underline{\mathrm{s} 12231-010-9133-0}$ 
Burns, B. R. 1991. The regeneration dynamics of Araucaria araucana. Dissertation. University of Colorado, Boulder, Colorado, USA.

Caldato, S. L., P. A. Floss, D. M. Da Croce, and S. J. Longhi. 1996. Estudo da regeneração natural, banco de sementes e chuva de sementes na Reserva Genética de Caçador, SC. Ciência Florestal 6(1):27-38.

Capparelli, A., N. Hilgert, A. H. Ladio, V. Lema, C. Llano, S. Molares, M. L. Pochettino, and P. Stampella. 2011. Paisajes culturales de Argentina: pasado y presente desde las perspectivas etnobotánica y paleoetnobotánica. Revista en Línea de la Asociación Argentina de Ecología del Paisaje 2:67-79.

Carvalho, M. M. X. 2006. O desmatamento das florestas de araucária e o Médio Vale do Iguaçu: una história de riqueza madeireira e colonizações. Dissertation. Universidade Federal de Santa Catarina, Florianópolis, Santa Catarina, Brazil.

Casas A., A. Valiente-Banuet, J. L. Viveros, J. Caballero, L. Cortés, P. Dávila, R. Lira, and I. Rodríguez. 2001. Plant resources of the Tehuacán-Cuicatlán Valley, Mexico. Economic Botany 55:129_ 166. http://dx.doi.org/10.1007/BF02864551

Castella, P. R., and R. M. A. Britez. 2004. Floresta com Araucária no Paraná: conservação e diagnóstico dos remanescentes florestais. Ministério do Meio Ambiente, Brasília Distrito Federal, Brazil.

Clement, C. R. 1999a. 1492 and the loss of Amazonian crop genetic resources. I. The relation between domestication and human population decline. Econonomic Botany 53(2):188-202. http://dx.doi.org/ 10.1007/BF02866498

Clement, C. R. 1999b. 1492 and the loss of Amazonian crop genetic resources. II. Crop biogeography at contact. Econonomic Botany 53(2):203-216. http://dx.doi.org/ 10.1007/BF02866499

Clement, C. R., and A. B. Junqueira. 2010a. Between a pristine myth and an impoverished future. Biotropica 42:534-536. http:// dx.doi.org/10.1111/j.1744-7429.2010.00674.X

Clement, C. R., M. Cristo-Araújo, G. C. d'Eeckenbrugge, A. A. Pereira, and D. Picanço-Rodrigues. 2010b. Origin and domestication of native Amazonian crops. Diversity 2:72-106. http://dx.doi.org/10.3390/d2010072

Cox, G. E. 2006. Exploración de la Patagonia norte-un viajero en el Nahuel Huapi (1862-1863). Continente, Buenos Aires, Argentina.

Davidson-Hunt, I., and F. Berkes. 2003. Learning as you journey: Anishinaabe perception of social-ecological environments and adaptive learning. Conservation Ecology 8(1):5. [online] URL: http://www.consecol.org/vol8/iss1/art5/

Dean, W. 1996. A ferro e fogo: a historia e a devastação da Mata Atlântica Brasileira. Companhia das Letras, São Paulo, Brazil.

Denevan, W. M., editor. 1992. The native population of the Americas. Second edition. University of Wisconsin Press, Madison, Wisconsin, USA.

Denevan, W. M. 2001. Cultivated landscapes of native Amazonia and the Andes. Oxford University Press, Oxford, USA.

Dillenburg, L. R., A. M. S. Franco, A. L. Coutinho, C. L. Korndorfer, C. C. Clebsh, L. S. Duarte, L. Ferla, L. M. G. Rosa,
L. G. R. Silva, M. L. Garbin, M. Mõsena, R. B. Zandavalli, and S. Yamasaki. 2009. Aspectos ecofisiológicos da regeneração de Araucaria angustifolia. Pages 57-66 in C. R. Fonseca, A. F. Souza, A. M. Leal-Zanchet, T. Dutra, A. Backes, and G. Ganade, editors. Floresta com araucária, ecologia, conservação e desenvolvimento sustentável. Holos, Ribeirão Preto, São Paulo, Brazil.

Dimitri, M. 1972. La region de los Bosques Andino-Patagónicos. Colección Científica 10. Instituto Nacional de Tecnología Agropecuaria (INTA), Buenos Aires, Argentina.

Duarte, L. S., L. R. Dillenburg, and L. M. G. Rosa. 2002. Assessing the role of light availability in the regeneration of Araucaria angustifolia. Australian Journal of Botany 50 (6):741751. http://dx.doi.org/10.1071/BT02027

Echeverria, C., C. Zamorano, and M. Cortes. 2004. Conservation and restoration of monkey puzzle (Araucaria araucana) forests in Chile. Final report. Universidad Catolica de Temuco, Temuco, Chile.

Ferreira, D. K., A. G. Nazareno, A. Mantovani, A., R. Bittencourt, A. M. Sebbenn, and M. S. Reis. 2012. Genetic analysis of 50-year old Brazilian pine (Araucaria angustifolia) plantations: implications for conservation planning. Conservation Genetics 13:435-442. http://dx.doi.org/ 10.1007/s10592-011-0296-8

Gallo, L., F. Izquierdo, L. J. Sanguinetti, A. Pinna, G. Siffredi, J. Ayesa, C. Lopez, A. Pelliza, N. Strizler, M. Gonzales Peñalba, L. Maresca, and L. Chauchard. 2004. Araucaria araucana forest genetic resources in Argentina. Pages 105-131 in B. Vinceti, W. Amaral, and B. Meilleur, editors. Challenges in managing forest genetic resource for livelihoods: examples from Argentina and Brazil. International Plant Genetic Resources Institute, Rome, Italy.

Gamble, C. 1990. El poblamiento paleolitico de Europa. Editorial Crítica, Barcelona, Spain.

González, M., M. Cortés, G. Izquierdo, L. Gallo, C. Echeverria, S. Bekkesy, and P. Montaldo. 2006. Araucaria araucana (Molina) K. Koch. Pages 36-53 in C. D. Zengers, editor. Las espécies arbóreas de los bosques templados de Chile y Argentinaautoecologia. Marisa Cuneo, Valdivia, Chile.

Guerra, M. P., V. Silveira, M. S. Reis, and L. Schneider. 2002. Exploração, manejo e conservação da araucária (Araucaria angustifolia). Pages 85-102 in L. L. Simões, and C. F. Lino, editors. Sustentável Mata Atlântica: a exploração de seus recursos florestais. Senac,São Paulo, Brazil.

Herrmann, T. M. 2005. Knowledge, values, uses and management of the Araucaria araucana forest by the indigenous Mapuche Pewenche people: a basis for collaborative natural resource management in southern Chile. Natural Resources Forum 29:120134. http://dx.doi.org/10.1111/j.1477-8947.2005.00121.x

Herrmann, T. M. 2006. Indigenous knowledge and management of Araucaria araucana forest in the Chilean Andes: implications for native forest conservation. Biodiversity and Conservation 15:647-662. http://dx.doi.org/10.1007/s10531-005-2092-6

Heusser, C. J. 1994. Paleoindians and fire during the late Quaternary in southern South America. Revista Chilena de Historia Natural 67:435-442. 
Heusser, C. J., J. Rabassa, A. Brandani, and R. Stuckenrath. 1988. Late-Holocene vegetation of the Andean Araucaria region, Province of Neuquén, Argentina. Mountain Research and Development 8:53-63. http://dx.doi.org/10.2307/3673406

Hueck, K. 1972. As florestas da América do Sul. Editora da Universidade de Brasília / Editora Polígono, São Paulo, Brazil.

Indrusiak, C., and S. A. Monteiro. 2009. Unidades de conservação na área de distribuição da Araucaria. Pages 267-272 in C. R. Fonseca, A. F. Souza, A. M. Leal-Zanchet, T. Dutra, A. Backes, and G. Ganade, editors. Floresta com araucária, ecologia, conservação e desenvolvimento sustentável. Holos, Ribeirão Preto, São Paulo, Brazil.

Iriarte, J., and H. Beling. 2007. The expansion of Araucaria forest in the southern Brazilian highlands during the last 4000 years and its implications for the development of the Taquara/Itarare tradition. Environmental Archaeology 12:115-127. http://dx.doi. org/10.1179/174963107x226390

Jaña, D. 1997. Las estructuras religiosas Mapuche-Pehuenche y su influencia en las acciones locales. Noticias de Antropología y Arqueología 2(12):1-6.

Kershaw, P., and B. Wagstaff. 2001. The southern conifer family Araucariaceae: history, status and value for paleoenvironment reconstruction. Annual Review of Ecology and Systematics 32:397-414. [online] URL: http://www.jstor.org/stable/2678646 http:// dx.doi.org/10.1146/annurev.ecolsys.32.081501.114059

Klabunde, G. 2012. Análise filogeográfica entre populações de Araucaria angustifolia (Bert.) O. Kuntze em sua área de distribuição natural. Dissertation. Universidade Federal de Santa Catarina, Florianópolis, Santa Catarina, Brazil.

Klanovicz, J. 2009. Kaingáng e Xokléng do sul do Brasil e a floresta: discutindo etno-história e história ambiental. Revista Brasileira de Agroecologia 4:3330-3333.

Klein, R. M. 1978. Mapa fitogeográfico do Estado de Santa Catarina. Herbário Barbosa Rodrigues, Itajaí, Brazil.

Ladio, A. H. 2001. The maintenace of wild edible plant gathering in a Mapuche community of Patagonia. Economic Botany 55:243254. http://dx.doi.org/10.1007/BF02864562

Ladio, A. H. 2011a. Traditional knowledge of edible wild native and exotic plants in the context of cultural change in human populations of arid Patagonia. Bioremediation, Biodiversity and Bioaviability 5:60-64.

Ladio, A. H. $2011 b$ Underexploited wild plant foods of northwestern Patagonia. Pages 1-16 in R. Filip, editor. Multidisciplinary approaches on food science and nutrition for the XXI century. Research Signpost, Kerala, India.

Ladio, A. H., and M. Lozada. 2000. Edible wild plant use in a Mapuche community of northwestern Patagonia. Human Ecology 28:5371-. http://dx.doi.org/10.1023/A:1007027705077

Ladio, A. H., and M. Lozada. 2001. Nontimber forest product use in two human populations from northwest Patagonia: a quantitative approach. Human Ecology 29:367-380. [online] URL: http://www.jstor.org/stable/4603407

Ladio, A. H., and M. Lozada. 2004a. Patterns of use and knowledge of wild edible plants in distinct ecological environments: a case study of a Mapuche community from northwestern Patagonia. Biodiversity and Conservation 13:11531173. http://dx.doi.org/10.1023/B:BIOC.0000018150.79156.50

Ladio, A. H., and M. Lozada. 2004b. Summer cattle transhumance and wild edible plant gathering in a Mapuche community of northwestern Patagonia. Human Ecology 32:225240. [online] URL: http://www.jstor.org/stable/4603513

Lara, A., M. Solari, P. Rutherford, O. Thiers, and R. Trecaman. 1999. Cobertura de la vegetación original de la ecorregión de los bisques valdivianos en Chile hacia 1550. Universidad Austral de Chile / World Wildlife Fund (WWF), Valdívia, Chile.

Macura, B., F. Zorondo-Rodríguez, M. Grau-Satorras, K. Demps, M. Laval, C. A. Garcia, and V. Reyes-García. 2011. Local community attitudes toward forests outside protected areas in India: impact of legal awareness, trust, and participation. Ecology and Society 16(3):10. http://dx.doi.org/10.5751/ES-04242-160310

Mantovani, A., L. P. C. Morellato, and M. S. Reis. 2004. Fenologia reprodutiva e produção de sementes em Araucaria angustifolia (Bert.) O. Kuntze. Revista Brasileira de Botânica 27:787-796. [online] URL: http://www.scielo.br/pdf/rbb/v27n4/v27n4a17

Mariño de Lovera, P. 1865. Cronica del reino del Chile (15531595): colección de historiadores del Chile (Tomo IV). História Nacional-Imprenta Ferrocarril, Santigo, Chile.

Mattos, J. R. 1994. O pinheiro-brasileiro. Artes Gráficas Princesa, Lages, Santa Catarina, Brazil.

Marchelli, P., C. Baier, C. Mengel, B. Ziegenhagen, and L. Gallo. 2010. Biogeographic history of the threatened species Araucaria araucana (Molina) K. Koch and implications for conservation: a case study with organelle DNA markers. Conservation Genetics 11:951-963. http://dx.doi.org/ 10.1007/s10592-009-9938-5

Mercuri, A. M. 2008. Human influence, plant landscape evolution and climate inferences from the archaeobotanical records of the Wadi Teshuinat area (Libyan Sahara). Journal of Arid Environment 72:1950-1967. http://dx.doi.org/10.1016/j. jaridenv.2008.04.008

Montaldo, P. R. 1974. La bioecologia de Araucaria araucana (Mol.) Koch. Boletin Instituto Florestal Latino-Americano de Investigación y Capacitación 46/48:3-55.

Musters. G. C. 2007. Vida entre los patagones un año de excursiones desde el estrecho de Magallanes hasta el Río Negro (1869-1870). Continente, Buenos Aires, Argentina.

Narvaes, I. S., D. A. Brena, and S. J. Longhi. 2005. Estrutura da regeneração natural em floresta ombrófila mista na floresta nacional de São Francisco de Paula, RS. Ciência Florestal 15 (4):331-342.

Newton, A. C. 2008. Conservation of tree species through sustainable use: how can it be achieved in practice? Oryx 42 (2):195-205. http://dx.doi.org/10.1017/S003060530800759X

Noelli, F. S. 2000. A ocupação humana na região sul do Brasil: arqueologia,debates e perspectivas. Revista da Universidade de São Paulo 44:218-169. [online] URL: http://www.usp.br/ revistausp/44a/02-francisosilva.pdf 
Noelli, F. S. 2008. The Tupi expansion. Pages 659-670 in $\mathrm{H}$. Silverman and W. H. Isbell, editors. The handbook of South American archaeology. Springer, New York, New York, USA. http://dx.doi.org/10.1007/978-0-387-74907-5 33

Oldfield, S., C. Lusty, and A. Mac Kinven. 1998. The world list of threatened trees. International Union for the Conservation of Nature (IUCN), World Conservation Press, Cambridge, UK.

Parque Nacional Lanín. 2011. Proyecto Pehuén "producción de semillas de Araucaria y su consumo por la fauna y por el hombre en el Parque Nacional Lanín." Síntesis periodo 2000-2010. Administración de Parques Nacionales (APN), Junin de los Andes, Neuquén, Argentina.

Parra, F., J. J. Blancas, and A. Casas. 2012. Landscape management and domestication of Stenocereus pruinosus (Cactaceae) in the Tehuacán Valley: human guided selection and gene flow. Journal of Ethnobiology and Ethnomedicine 8:32 [online] URL: http://www.ethnobiomed.com/content/8/1/32

Prober, S. M., M. H. O'Connor, and F. J. Walsh. 2011. Australian Aboriginal peoples' seasonal knowledge: a potential basis for shared understanding in environmental management. Ecology and Society 16(2): 12. [online] URL: http://www.ecologyandsociety. org/vol16/iss2/art12/

Puchalsky, A., M. Mantovani, and M. S. Reis. 2006. Variação em população naturais de Araucaria angustifolia (Bert.) O. Kuntze associada a condições edafo-climáticas. Scientia Forestalis 70:137-148.

Reis, A. 1993. Manejo e conservação das florestas catarinenses. Dissertation. Universidade Federal de Santa Catarina, Florianópolis, Santa Catarina, Brazil.

Reis, M. S., N. Peroni, A. Mariot, W. Steenbock, S. Filippon, C. Vieira da Silva, and A. Mantovani. 2010. Uso sustentável e domesticação de espécies da Floresta Ombrófila Mista. Pages 183-214 in L. C. Ming, M. C. M. Amorozo, and C. W. Kffuri, editors. Agrobiodiversidade no Brasil : experiências e caminhos da pesquisa. NUPPEA, Recife, Pernambuco, Brazil.

Reis, M. S., A. Mantovani, J. Zago Da Silva, A. Mariot, B. Bittencourt, A. G. Nazareno, S. K. Ferreira, F. Steiner, T. Montagna, A. A. L. S. Silva, C. D. Fernandes, G. Altrak, and L. G. Figueredo. 2012. Distribuição da diversidade genética e conservação de espécies arbóreas em remanescentes florestais de Santa Catarina. Pages 143-169 in A. C. Vibrans, L. Sevegnani, A. L. De Gasper, and D. V. Lingner, editors. Inventário florístico florestal de Santa Catarina. Universidade Regional de Blumenau (FURB), Santa Catarina, Brazil.

Reis, M. S., C. Vieira da Silva, A. G. Mattos, A. Zechini, A. Mantovani, and N. Peroni. 2013. Caívas and their contribution to the conservation of to the conservation of Atlantic forest landscapes in Brazil. Pages 151-156 in W. De Boeff, A. Subedi, N. Peroni, M. Thijssen, and E. O'Keeffe, editors. Community biodiversity management: promoting resilience and the conservation of plant genetic resources. Routledge, London, UK.

Reitz, R., and R. M. Klein. 1966. Araucariceae. Flora ilustrada catarinense. Herbário Barbosa Rodriguês, Itajaí, Santa Catarina, Brazil.
Ribeiro, M. C., J. P. Metzger, A. C. Martensen, F. J. Ponzoni, and M. M. Hirota 2009. The Brazilian Atlantic forest: how much is left, and how is the remaining forest distributed? Implications for conservation. Biological Conservation 142:1141-1153. http://dx. doi.org/10.1016/j.biocon.2009.02.021

Rondanelli-Reyes, M. J. 2000. Historia vegetacional del bosque andino de Araucaria araucana (Molina) k. Koch, en la cuenca de Alto Valle del Río Biobió, Provincia de Lonquimay, Chile centrosur, durante el Holocieno. Análisis palinológico del perfil Miraflores 2. Zeitungsblatt Geologie und Palaontologie 7/8:10411051.

Rondanelli-Reyes, M. J. 2001. Análises palinológico del perfil San Pedro, valle de Lonquimay, Andes de Chile centro-sur, durante el Holoceno tardio. Pages 147-153 in Proceedings of the XI Simpósio Argentino de Peleobotánica y Palinologia. Publicación Especial 8. Asocición Pelontológica Argentina, Buenos Aires, Argentina.

Ruiz, E., F. González, C. Torres-Diaz, G. Fuentes, M. Mordones, T. Stuessy, R. Samuel, J. Becerra, and M. Silva. 2007. Genetic diversity and differentiation within and among Chilean populations of Araucaria araucana (Araucariaceae) based on allozyme variability. Taxon 56:1221-1228. http://www.jstor.org/ $\underline{\text { stable/25065913 }}$

Sanguinetti, J. 2008. Producción y predación de semillas, efectos de corto y largo plazo sobre el reclutamiento de plántulas-caso de estudio: Araucaria araucana. Dissertation. Universidad de Comahue, San Carlos de Bariloche, Rio Negro, Argentina.

Santos Fita, D., E. J. Naranjo Pineda, and R. Mariaca Méndez. 2009. Hacia un etnoconservacionismo de la fauna silvestre. Pages 97-117 in E. M. Costa Neto, D. Santos Fita, and M. Vargas Clavijo, editors. Manual de etnozoología. Tundra Ediciones, Madrid, Spain.

Santos, A. J., N. M. Corso, G. Martins, and E. Bittencourt. 2002. Aspectos produtivos e comerciais do pinhão no Estado do Paraná. Revista Floresta 32:163-169.

Santos, S. C. 1973. Índios e brancos no sul do Brasil: a dramática experiência dos Xokleng. Edune, Florianópolis, Santa Catarina, Brazil.

Schmitz, P. I. 2009. Povos indígenas associados a floresta com araucária. Pages 45-56 in C. R. Fonseca, A. F. Souza, A. M. LealZanchet, T. Dutra, A. Backes, and G. Ganade, editors. Floresta com araucária, ecologia, conservação e desenvolvimento sustentável. Holos, Ribeirão Preto, São Paulo, Brazil.

Schuster, W. T., and C. L. Löwen-Sahr. 2009. O faxinal do presente e o faxinal do passado: evolução do uso da terra no Faxinal Saudade Santa Anita - Turvo (PR). Pages 1-21 in Anais do XIX Encontro Nacional de Geografia Agrária. AGRÁRIA/ PPG Geografia Humana-FFLCH / USP, São Paulo, Brazil.

Shepard, G., and H. Ramirez. 2011. "Made in Brazil": human dispersal of the Brazil nut (Bertholletia excelsa, Lecythidaceae) in ancient Amazonia. Economic Botany 65:44-65. http://dx.doi. org/10.1007/s12231-011-9151-6

Sheperd, J. D., and R. S. Ditgen. 2012. Rodent handling of Araucaria araucana seeds. Austral Ecology 38(1)23. http://dx.doi. org/10.1111/j.1442-9993.2012.02366.x 
Shepherd, J. D., R. S. Ditgen, and J. Sanguinetti. 2008. Araucaria araucana and the Austral parakeet: pre-dispersal seed predation on a masting species. Revista Chilena de Historia Natural 81:395401. http://dx.doi.org/10.4067/S0716-078X2008000300008

Solórzano-Filho, J. A. 2001. Demografia e ecologia da dispersão de sementes de Araucaria angustifolia (Bert.) Kutze (Araucariaceae), numa população relictual em Campos do Jordão, SP. Dissertation, Universidade de São Paulo, São Paulo, Brazil.

Souza, A. F., C. Forgiarini, S. J. Longhi, and D. A. Brena. 2008. Regeneration patterns of a long-lived dominant conifer and the effects of logging in southern South America. Acta Oecologica 34:221-232. http://dx.doi.org/10.1016/j.actao.2008.05.013

Stefenon, V. M., H. Behling, O. Gailing, and F. Reiner. 2008. Evidences of delayed size recovery in Araucaria angustifolia populations after post-glacial colonization of highlands in southeastern Brazil. Anais da Academia Brasileira de Ciências 80 (3):433-443. http://dx.doi.org/10.1590/S0001-37652008000300005

Thomé, N. 1995. Ciclo da Madeira. Caçador.Impressora Universal, Caçador, Santa Catarina, Brazil.

Torri, M. C., and T. M. Herrmann. 2010. Biodiversity conservation versus rural development: what kind of possible harmonization? The case study of Alwar District, Rajasthan, India. Journal of Human Ecology 31:93-101.

Toupal, R. S. 2003. Cultural landscapes as a methodology for understanding natural resource management impacts in the western United States. Conservation Ecology 7(1):12. [online] URL: http://www.consecol.org/vol7/iss1/art12

Veblen, T. T. 1982. Regeneration patterns in Araucaria araucana forest in Chile. Journal of Biogeography 9:11-28. [online] URL: http://www.jstor.org/stable/2844727

Veblen, T. T., R. B. Burns, T. Kitzberger, A. Lara, and R. Villalba. 1995. The ecology of the conifers of southern South America. Pages 120-155 in N. Enright, and R. Hill, editors. Ecology of the southern conifers. Melbourne University Press, Parkville, Melbourne, Australia.

Vibrans, A. C., L. Sevegnani, A. Uhlmann, L. A. Schorn, M. G. Sobral, A. L. Gasper, D. V. Lingner, E. Brogni, G. Klemz, M. B. Godoy, and M. Verdi. 2011. Structure of mixed ombrophyllous forests with Araucaria angustifolia (Araucariaceae) under external stress in southern Brazil. Revista de Biologia Tropical 59:1371-1387.

Vieira, E. M., and G. Iob. 2009. Dispersão e predação de sementes de Araucaria angustifolia. Pages 85-96 in C. R. Fonseca, A. F. Souza, A. M. Leal-Zanchet, T. Dutra, A. Backes, and G. Ganade, editors. Floresta com araucária, ecologia, conservação $e$ desenvolvimento sustentável. Holos, Ribeirão Preto, São Paulo, Brazil.

Vieira da Silva, C., G. Martins, N. Steiner, K. L. Santos, R. Camargo, A. Mantovani, R. R. Cubo, M. P. Guerra, and M. S. Reis. 2011. Araucaria angustifolia Pinheiro-brasileiro. Pages 134 150 in L. Coradin, A. Siminski, and A. Reis, editors. Espécies nativas da flora Brasileira de valor econômico atual ou potencial: plantas do futuro-região sul. Ministério do Meio Ambiente, Brasília Distrito Federal, Brazil.
Vieira da Siva, C., and M. S. Reis. 2009. Produção de pinhão na região de Caçador, SC: aspectos da obtenção e sua Importância para comunidades locais. Ciência Florestal 19:363-374.

Vieira, E. E. 2004. Simbolismo e reelaboração na cultura material dos Xokleng. Dissertation. Universidade Federal de Santa Catarina, Florianópolis, Santa Catarina, Brazil.

Villagrán, C. 2001. Um modelo de la historia de la vegetación de la Cordillera de la costa de Chile centro sur: la hipótese glacial de Darwin. Revista Chilena de Historia Natural 74:793-803. http:// dx.doi.org/10.4067/S0716-078X2001000400007

Woods, W. I., W. G. Teixeira, J. Lehmann, S. Steiner, A. M. G. A. WinklerPrins, and L. Rebellato, editors. 2009. Amazonian dark earths: Wim Sombroek's vision. Springer, New York, New York, USA. http://dx.doi.org/10.1007/978-1-4020-9031-8

Xu, J., E. T. Ma, D. Tashi, Y. Fu, Z. Lu, and D. Melick. 2005. Integrating sacred knowledge for conservation: cultures and landscapes in southwest China. Ecology and Society 10(2):7. [online] URL: http://www.ecologyandsociety.org/vol10/iss2/art7/

Zamorano, C., M. Cortés, C. Echeverria, P. Hechenleitner, and A. Lara. 2008. Experiencias de restauración con especies forestales amenazadas en Chile. Pages 18-36 in M. GonzálezEspinosa, J. M. Rey-Benayas, and N. Ramírez-Marcial, editors. Restauración de bosques en America Latina. FIRE / MundiPrensa, Mexico City, Mexico.

Zechini, A. A., G. Schussler, J. Z. Silva, A. G. Mattos, N. Peroni, A. Mantovani, and M. S. Reis. 2012. Produção, comercialização e identificação de variedades de pinhão no entorno da Floresta Nacional de Três Barras - SC. Biodiversidade Brasileira 2:74-82. 